\title{
Efikasi Kombinasi Herbisida Metil Metsulfuron dan Asam Asetat pada Lahan Perkebunan Kelapa Sawit (Elaeis guineensis Jacq.) Menghasilkan
}

\section{(The Efficacy of the Combination of Methyl Metsulfuron Herbicide and Acetic Acid on Plantations of Mature Oil Palm [Elaeis guineensis Jacq.])}

\author{
Iis Okta Arbania ${ }^{1}$, Albertus Sudirman ${ }^{2 *}$, Sismita Sari ${ }^{2}$, Mirodi Syofian ${ }^{2}$ \\ ${ }^{1}$ Program Studi Produksi dan Manajemen Industri Perkebunan Jurusan Budidaya Tanaman \\ Perkebunan, Politeknik Negeri Lampung Jl. Soekarno-Hatta No. 10 Rajabasa, Bandar Lampung, \\ 35144, Telp.: (0721) 703995, Fax.: (0721) 787309, ${ }^{2}$ Jurusan Budidaya Tanaman Perkebunan, \\ Politeknik Negeri Lampung Jl. Soekarno-Hatta No. 10 Rajabasa, Bandar Lampung, 35144, Telp.: \\ (0721) 703995, Fax.: (0721) 787309 \\ E-mail: albertus@polinela.ac.id
}

\section{ARTICLE INFO}

Article history

Submitted: November 20, 2019

Accepted: May 9, 2021

Published: May 15, 2021

Keywords:

acetic acid

herbicide,

methyl metsulfuron,

percent weed cover, weed dry weight

\section{ABSTRACT}

One of the obstacles that resulted in a decrease in palm oil production was the presence of weeds. Weed control needs to be done to suppress weed growth. A mixture of methyl metsulfuron herbicide and acetic acid herbicide can be used to control weeds. This research was conducted in Politeknik Negeri Lampung's Teaching Farm. This study used a factorial randomized block design with two factors, and each treatment combination was repeated three times. The first factor is the methyl metsulfuron herbicide $20 \%$ with 3 level doses: 0 g.ha ${ }^{-1}, 45$ $\mathrm{g}, \mathrm{ha}^{-1}$, and $75 \mathrm{~g} . \mathrm{ha}^{-1}$ and the second factor is acetic acid herbicide 20\% with 3 level doses: $0 \mathrm{ml} . \mathrm{ha}^{-1}$, $225 \mathrm{l} . \mathrm{ha}^{-1}$, and $315 \mathrm{l} . \mathrm{ha}^{-1}$. The result showed that the combination of methyl metsulfuron herbicide $75 \mathrm{~g} . \mathrm{ha}^{-1}$ and acetic acid herbicide 315 l.ha ${ }^{-1}$ effective reduce weed dry weight up to 5.50 grams at 5 WAA and reduce weed cover percentage to $8 \%$ at 6 WAA. The dominant weeds that arises after the application of the methyl metsulfuron herbicide and acetic acid is Asystasia gangetica, Paspalum conjugatum, Panicum dichotomiflorum, Stachytarpeta indica, and Imperata cylindrica. Copyright (C) 2021 Author(s). This work is licensed under a Creative Commons AttributionShareAlike 4.0 International License.

\section{PENDAHULUAN}

Kelapa sawit merupakan tanaman penghasil CPO. Minyak kelapa sawit (CPO) merupakan salah satu komoditi yang diekspor Indonesia. Jumlah minyak kelapa sawit yang diekspor setiap tahunnya mengalami kenaikan, pada tahun 2000 Indonesia mengeskspor 4.110 ton dan mengalami peningkatan pada tahun 2014 sebanyak 22.892,4 ton (Badan Pusat Statistik, 2020). Produksi minyak kelapa sawit dipengaruhi oleh proses budidaya yang baik dan benar. Budidaya tanaman kelapa sawit memiliki banyak kendala yang membuat produksi tidak maksimum dan tidak efisien. Salah satu kendalanya adalah masalah gulma. 
Gulma merupakan organisme pengganggu tanaman (OPT) yang berada di lahan budidaya. Adanya gulma yang tidak dikendalikan di lahan budidaya menyebabkan kompetisi penggunaan unsur hara, $\mathrm{CO}_{2}$, ruang tumbuh, dan dapat mengeluarkan alelokimia (Onarely et al., 2016; Gultom et al., 2017). Pengendalian gulma memerlukan biaya yang masuk dalam proses pemeliharan. Besarnya biaya pemeliharaan pada TM dapat mencapai Rp11.600.114,00 ha $^{-1} \cdot$ tahun $^{-1}$ di perkebunan rakyat (Sinaga et al., 2018). Selain itu, gulma dapat menghambat proses pemungutan brondolan kelapa sawit pada saat pemanenan (Nugraha et al., 2018). Beberapa jenis gulma invasif yang sering terdapat di perkebunan kelapa sawit, antara lain Imperata cylindrica, Asystasia gangetica, Cyperus hirtus, dan Stachytarpeta indica (Hutapea et al., 2015). Jenis gulma tersebut menyebar dengan cepat di perkebunan karena memiliki kemampuan berkembang biak secara vegetatif dan generatif.

Berdasarkan uraian masalah yang telah dikemukan, perlu dilakukan pengendalian terhadap gulma guna mengurangi persaingan dalam penyerapan unsur hara dan mempermudah saat proses pemanenan. Pengendalian yang dapat digunakan salah satunya adalah pengendalian menggunakan herbisida metil metsulfuron dan asam asetat yang dikombinasikan. Teknologi pencampuran herbisida merupakan salah satu upaya meningkatkan efektifitas, memperluas spektrum pengendalian gulma, mengurangi residu herbisida dan mencegah munculnya jenisjenis gulma resisten, komponen campuran umumnya memiliki dosis lebih rendah dibandingkan dosis herbisida tunggal (Umiyati \& Kurniadie, 2018). Hasil penelitian terdahulu menunjukkan bahwa aplikasi herbisida menyebabkan terjadinya perubahan dominansi gulma (Oktavia et al., 2019). Tujuan dari penelitian ini adalah mendapatkan dosis kombinasi herbisida metil metsulfuron dan asam asetat yang efektif mengendalikan gulma pada lahan perkebunan sawit serta dominansi gulma pada perkebunan kelapa sawit fase tanaman menghasilkan TM.

\section{METODE PENELITIAN}

Penelitian ini dilaksanakan pada bulan Januari 2017 sampai Maret 2017 di Kebun Percobaan Kelapa Sawit (TM 7) dan Laboratorium Tanaman II Politeknik Negeri Lampung. Bahan-bahan yang digunakan dalam penelitian ini adalah herbisida metil metsulfuron, herbisida asam asetat, air, kantong plastik, kantong kertas (amplop), tali rafia, serta gulma yang terdapat di lahan praktik. Alat yang digunakan adalah roll meter, ajir, palu, oven, gunting, ember, sprayer, gelas ukur, frame ukuran $50 \mathrm{~cm} \times 100 \mathrm{~cm}$, timbangan, dan alat tulis.

Rancangan penelitian yang digunakan dalam percobaan ini adalah Rancangan Acak Kelompok (RAK) faktorial, dengan dua faktor yaitu dosis herbisida metil metsufuron dan dosis asam asetat. Faktor pertama herbisida metil metsufuron 20\% dengan 3 taraf dosis herbisida yaitu 0 g.ha ${ }^{-1}\left(M_{0}\right)$, 45 g.ha ${ }^{-1}\left(M_{1}\right)$, dan 75 g.ha ${ }^{-1}\left(M_{2}\right)$. Faktor kedua yaitu asam asetat $20 \%$ dengan 3 taraf yaitu asam asetat $0 \mathrm{ml} \cdot \mathrm{ha}^{-1}\left(\mathrm{~A}_{0}\right)$, asam asetat $2251 . \mathrm{ha}^{-1}\left(\mathrm{~A}_{1}\right)$ dan asam asetat 315 1.ha $^{-1}\left(\mathrm{~A}_{2}\right)$, sehingga terdapat 9 kombinasi perlakuan dengan 3 ulangan, sehingga terdapat 27 satuan percobaan. Volume larutan yang akan digunakan adalah $180 \mathrm{ml}$. Analisis sidik ragam dilakukan terhadap data bobot kering dan persen penutupan gulma yang diperoleh, diteruskan dengan uji Beda Nyata Terkecil pada taraf kesalahan 5\%. Pengamatan dilakuan terhadap bobot kering gulma dan nilai SDR. 


\section{HASIL DAN PEMBAHASAN}

\section{Analisis Vegetasi Gulma}

Analisis vegetasi gulma merupakan metode yang digunakan untuk mengetahui jenisjenis gulma yang terdapat disuatu wilayah, biasanya analisis vegetasi gulma dilakukan sebelum pengaplikasian herbisida. Hal ini dilakukan agar herbisida yang digunakan dapat mengenai sasaran secara tepat dan efisien. Hasil analisis menunjukkan adanya 27 spesies gulma yang tumbuh dengan curah hujan 202,8 mm. Spesies gulma yang ditemukan yaitu: (1) Melastoma sp., (2) Oxalis barrelieri L., (3) Imperata cylindrica, (4) Synedrella nodiflora L. Gaetern, (5) Paspalum conjugatum P.J. Bergius, (6) Stachytarpeta indica (L.) Valh., (7) Asystasia gangetica (L.) T. Anders, (8) Cyperus rotundus, (9) Panicum dichotomiflorum Bergius, (10) Cyperus kyllingia Endl., (11) Ottochloa nodosa, (12) Mimosa pudica L., (13) Mucuna bracteata, (14) Hyptis capitata, (15) Croton hirtus L'Hér., (16) Commelina benghalenis L., (17) Ageratum conyzoides, (18) Nephrolepis exaltata, (19) Spigelia sp., (20) Clidemia hirta, (21) Elaeis guineensis Jacq., (22) Eleusine indica Gaertn, (23) Phyllanthus niruri, (24) Syzygium polyanthum, (25) Sorghum halepense, (26) Porophyllum ruderale, dan (27) Pterospermum javanicum.

\section{Persen Penutupan Gulma}

Berdasarkan hasil analisis data menunjukkan bahwa terjadi interaksi antara kombinasi herbisida metil metsulfuron dan herbisida asam asetat. Hal ini menunjukkan bahwa penggunaan herbisida sebagai pengendalian gulma mampu menekan persen penutupan gulma dengan baik. Selain itu, kombinasi dosis yang berbeda juga berpengaruh terhadap besarnya persen penutupan gulma.

Tabel 1. Rerata pengaruh kombinasi herbisida metil metsulfuron dan asam asetat terhadap persen penutupan gulma pada $6 \mathrm{MSA}$

\begin{tabular}{|c|c|c|c|c|}
\hline \multirow{2}{*}{ Metil metsulfuron } & \multicolumn{3}{|c|}{ Asam asetat } & \multirow{2}{*}{ Rerata } \\
\hline & $0 \mathrm{ml} \cdot \mathrm{ha}^{-1}$ & 225 1.ha $^{-1}$ & 315 1.ha $^{-1}$ & \\
\hline \multicolumn{5}{|c|}{------------------ $\%$------------------ } \\
\hline 0 g.ha ${ }^{-1}$ & $81,75 \mathrm{a}$ & $15,25 \mathrm{~b}$ & $10,25 \mathrm{~b}$ & $35,75 \mathrm{a}$ \\
\hline 45 g.ha $a^{-1}$ & $18,75 \mathrm{~b}$ & $11,50 \mathrm{~b}$ & $6,75 \mathrm{~b}$ & $12,33 \mathrm{~b}$ \\
\hline 75 g.ha ${ }^{-1}$ & $20,42 \mathrm{~b}$ & $12,75 \mathrm{~b}$ & $8,00 \mathrm{~b}$ & $13,72 \mathrm{~b}$ \\
\hline Rerata & $40,31 \mathrm{a}$ & $13,17 \mathrm{~b}$ & $8,33 \mathrm{~b}$ & \\
\hline
\end{tabular}

Keterangan: Nilai rata-rata yang diikuti oleh huruf yang sama tidak berbeda nyata menurut Uji BNT pada taraf nyata $5 \%(\alpha=0,5)$

Berdasarkan hasil Tabel 1, perlakuan dosis kombinasi yang berbeda berpengaruh terhadap besar atau kecilnya persentase penutupan gulma. Interaksi antara penggunaan herbisida metil metsulfuron dan herbisida asam asetat terjadi pada $6 \mathrm{MSA}$, kombinasi terbaik adalah $\mathrm{M}_{2} \mathrm{~A}_{2}$ dengan dosis herbisida metil metsulfuron 75 g.ha ${ }^{-1}$ dan asam asetat $3151 . \mathrm{ha}^{-1}$ dengan nilai persen penutupan gulma terkecil mencapai $8 \%$. Hal ini diduga karena mekanisme kerja dari metil metsulfuron yang menganggu proses fisiologi jaringan lalu dialirkan kedalam jaringan gulma dan mematikan jaringan sasarannya seperti daun, titik tumbuh, tunas sampai ke perakarannya (Kuvaini, 
2011; Madusari, 2016), serta mekanisme kerja asam asetat dengan menimbulkan efek terbakar pada bagian yang tekena saja sehingga bagian yng tidak terkena terutama ruas batang dengan cepat akan tumbuh tunas (Pujisiswanto, 2012).

\section{Bobot Kering Gulma}

Berdasarkan Tabel 2, terdapat interaksi antara kombinasi herbisida metil metsulfuron dan asam asetat setelah aplikas. Pada 5 MSA, bahwa herbisida metil metsulfuron 75 g.ha $^{-1}$ yang dicampur herbisida asam asetat $3151 . \mathrm{ha}^{-1}$ mampu menekan pertumbuhan gulma hingga mencapai 5,03 gram. Herbisida kombinasi $\mathrm{M}_{2} \mathrm{~A}_{2}$ dapat mengendalikan gulma 88,03\% lebih baik daripada perlakuan $\mathrm{M}_{0} \mathrm{~A}_{0}$ (kontrol).

Tabel 2. Rerata pengaruh kombinasi herbisida metil metsulfuron dan asam asetat terhadap bobot kering pada 6 MSA

\begin{tabular}{|c|c|c|c|c|}
\hline \multirow{2}{*}{ Metil metsulfuron } & \multicolumn{3}{|c|}{ Asam asetat } & \multirow{2}{*}{ Rerata } \\
\hline & $0 \mathrm{ml} \cdot \mathrm{ha}^{-1}$ & 225 l.ha $^{-1}$ & 315 1.ha ${ }^{-1}$ & \\
\hline \multicolumn{5}{|c|}{ g.m² - } \\
\hline 0 g.ha ${ }^{-1}$ & $32,67 \mathrm{a}$ & $5,87 \mathrm{~d}$ & $25,03 \mathrm{a}$ & $21,22 \mathrm{a}$ \\
\hline $45 \mathrm{~g} \cdot \mathrm{ha}^{-1}$ & $5,67 \mathrm{~d}$ & $24,27 \mathrm{a}$ & $11,13 \mathrm{c}$ & $13,69 \mathrm{a}$ \\
\hline 75 g.ha ${ }^{-1}$ & $11,27 \mathrm{~b}$ & $8,57 \mathrm{~d}$ & $6,63 \mathrm{~d}$ & $8,82 \mathrm{~b}$ \\
\hline Rerata & 16,57 & 12,90 & 14,27 & \\
\hline
\end{tabular}

Keterangan: Nilai rata-rata yang diikuti oleh huruf yang sama tidak berbeda nyata menurut Uji BNT pada taraf nyata $5 \%(\alpha=0,5)$

Pada Tabel 2 pengaruh kombinasi herbisida metil metsulfuron dengan herbisida asam asetat terhadap bobot kering gulma 6 MSA menunjukkan adanya interaksi pada kombinasi herbisida metil metsulfuron 75 g.ha ${ }^{-1}$ dan asam asetat 315 l.ha ${ }^{-1}$ dengan nilai 6,63 g.m ${ }^{-2}$. Penurunan nilai bobot kering secara bertahap terjadi pada perlakuan herbisida metil metsulfuron $75 \mathrm{~g} . \mathrm{h} \mathrm{a}^{-1}$ dan asam asetat 315 1.ha ${ }^{-1}$ yang merupakan dosis aplikasi paling tinggi. Kedua dosis tersebut mengalami penurunan bobot kering yang signifikan dalam setiap kombinasinya masing-masing.

Hasil pengamatan bobot kering gulma menunjukkan bahwa penggunaan herbisida metal metsulfuron dosis 75 g.ha ${ }^{-1}$ mampu mengendalikan gulma dengan tingkat pengendalian hingga 41,56\% dari perlakuan control pada 6 MSA, namun pada 7 MSA perlakuan tersebut tidak berbedanyata dengan perlakuan control. Pengendalian dengan herbisida asam asetat hanya mampu mengendaikan gulma dari 2 MSA hingga 5 MSA dengan dosis $3151 . \mathrm{ha}^{-1}$ mampu mengendalikan hingga 32\% dibandingkan dengan perlakuan kontrol. Hal ini diduga bahwa asam asetat yang bersifat kontak yang menghambat laju fotosintesis dengan kerusakan terjadi pada bagian gulma yang terkena saja. Asam asetat menghambat laju fotosintesis melalaui kebocoran pada membran sel, penuruna konduktansi stomata dan menginduksi penutupan stomata, penurunan laju transpirasi, penurunan serapan $\mathrm{CO}_{2}$, peningkatan $\mathrm{O}_{2}$, menghambat sintesis protein, dan penurunan kadar klorofil (Pujisiswanto, 2015). 
Tabel 9. Bobot kering gulma pada 0 MSA, 1 MSA, 2 MSA, 3 MSA, 4 MSA, 5 MSA, 6 MSA, dan 7 MSA

\begin{tabular}{|c|c|c|c|c|c|c|c|c|c|}
\hline \multirow{2}{*}{ Perlakuan } & \multicolumn{7}{|c|}{ Bobot kering gulma $\left(\mathrm{g} \cdot \mathrm{m}^{-2}\right)$} & \multirow[b]{2}{*}{$7 \mathrm{MSA}$} & \multirow{2}{*}{ Total } \\
\hline & $0 \mathrm{MSA}$ & $1 \mathrm{MSA}$ & $2 \mathrm{MSA}$ & $3 \mathrm{MSA}$ & 4 MSA & $5 \mathrm{MSA}$ & $6 \mathrm{MSA}$ & & \\
\hline \multicolumn{10}{|c|}{ Metil metsulfuron } \\
\hline 0 g.ha ${ }^{-1}$ & 58,53 & 45,54 & $46,96 \mathrm{a}$ & $28,32 \mathrm{a}$ & $17,67 \mathrm{~b}$ & $20,42 \mathrm{a}$ & $21,22 \mathrm{a}$ & 25,78 & $264,44 a$ \\
\hline $45 \mathrm{~g} \cdot \mathrm{ha}^{-1}$ & 54,16 & 48,12 & $31,84 \mathrm{~b}$ & $16,19 b$ & $23,53 \mathrm{a}$ & $21,20 \mathrm{a}$ & $13,69 \mathrm{a}$ & 19,49 & $228,22 \mathrm{a}$ \\
\hline 75 g.ha ${ }^{-1}$ & 42,48 & 40,48 & $22,60 \mathrm{~b}$ & $12,77 \mathrm{~b}$ & $11,7 \mathrm{c}$ & $9,02 \mathrm{~b}$ & $8,82 \mathrm{~b}$ & 13,97 & $161,97 \mathrm{~b}$ \\
\hline BNT & 25,05 & 20,56 & 14,29 & 7,87 & 4,97 & 10,11 & 7,67 & 12,66 & 68,75 \\
\hline \multicolumn{10}{|l|}{ Asam asetat } \\
\hline $0 \mathrm{ml} \cdot \mathrm{m}^{-2}$ & 48,51 & 54,07 & $46,94 \mathrm{a}$ & 29,33 a & $24,86 \mathrm{a}$ & $29,40 \mathrm{a}$ & $16,57 \mathrm{a}$ & 25,42 & $275,10 a$ \\
\hline 225 l.ha $^{-1}$ & 60,06 & 41,00 & $24,00 \mathrm{~b}$ & $14,69 \mathrm{~b}$ & $15,92 \mathrm{~b}$ & $11,54 \mathrm{~b}$ & $12,90 \mathrm{a}$ & 19,90 & $190,01 \mathrm{~b}$ \\
\hline 315 l.ha $^{-1}$ & 56,60 & 39,08 & $30,46 \mathrm{~b}$ & $13,26 \mathrm{~b}$ & $12,26 \mathrm{~b}$ & $9,70 \mathrm{~b}$ & $14,27 \mathrm{a}$ & 13,91 & $189,52 \mathrm{a}$ \\
\hline BNT & 25,05 & 20,56 & 14,29 & 7,87 & 4,97 & 10,11 & 7,67 & 12,66 & 68,75 \\
\hline
\end{tabular}

Keterangan: Nilai rata-rata yang diikuti oleh huruf yang sama tidak berbeda nyata menurut Uji BNT pada taraf nyata $5 \%(\alpha=0,5) ;$ MSA = minggu setelah aplikasi

\section{Summed Dominance Ratio (SDR)}

Summed dominance ratio (SDR) merupakan variabel penilaian yang digunakan untuk menentukan dominasi gulma pada saat percobaan. Nilai SDR diperoleh berdasarkan bobot kering gulma pada setiap petak perlakuan pada pengamatan terakhir. Nilai SDR dapat menentukan tingkat dominasi dari suatu spesies gulma dalam komunitas gulma. Mengetahui komunitas gulma yang dominan di lahan dapat mempermudah pemilihan cara pengendalian gulma agar lebih efektif dan efisien, sehingga dapat menekan biaya, waktu, dan tenaga kerja.

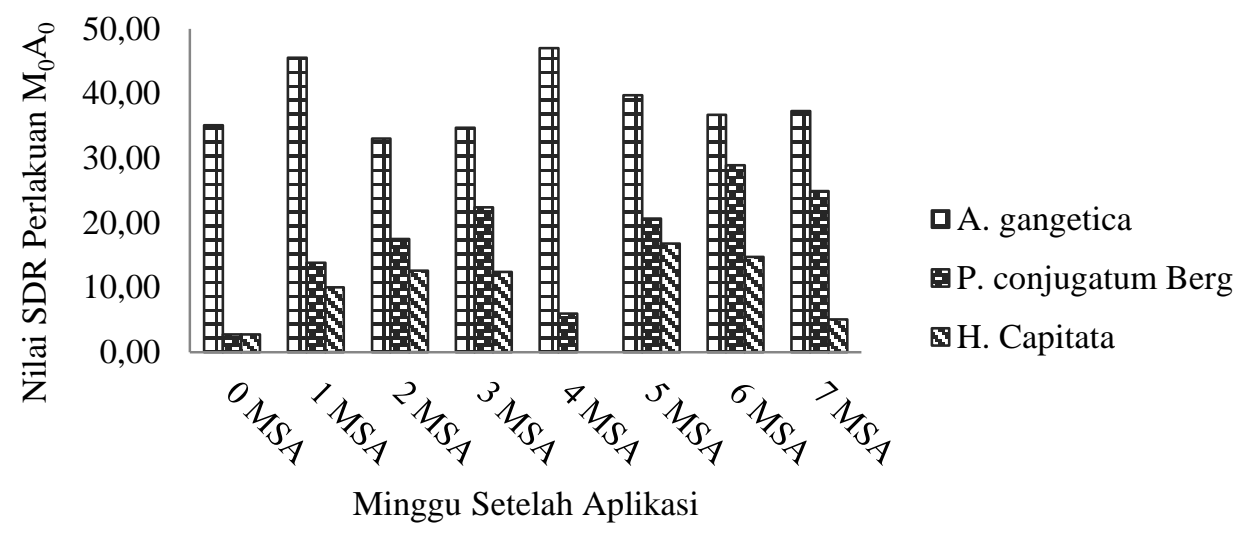

Gambar 1. Perbandingan tiga spesies gulma dominan akibat perlakuan metil metsulfuron 0 g.ha ${ }^{-1}$ dan asam asetat $0 \mathrm{ml}^{-\mathrm{ha}^{-1}}$

Pelakuan kontrol $\left(\mathrm{M}_{0} \mathrm{~A}_{0}\right)$ dengan dosis kombinasi herbisida metil metsulfuron 0 g.ha ${ }^{-1}$ dengan asam asetat $0 \mathrm{ml} \cdot \mathrm{ha}^{-1}$ menunjukan A. gangetica (L.) T. Anders dan H. capitata merupakan gulma golongan berdaun lebar yang mendominasi, sedangkan golongan gulma rumputan yang mendominasi adalah P. dycotomiflorum (Gambar 4). A. gangetica (L.) T. Anders merupakan spesias yang paling dominan dari spesies lain dengan nilai SDR 35,07\% pada 0 MSA, dan mencapai $47 \%$ pada 4 MSA. 


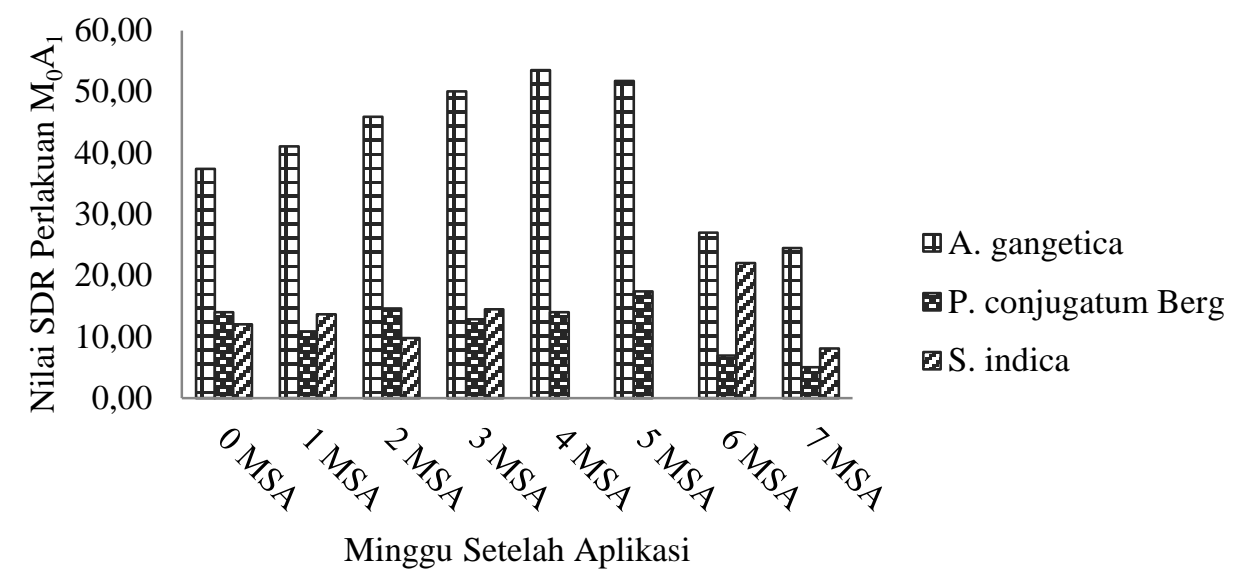

Gambar 2. Perbandingan tiga spesies gulma dominan akibat perlakuan metil metsulfuron 0 g.ha ${ }^{-1}$ dan asam asetat $225 \mathrm{ml} \mathrm{ha}^{-1}$

Pada perlakuan $\mathrm{M}_{0} \mathrm{~A}_{1}$ dosis kombinasi herbisida metil metsulfuron 0 g.ha ${ }^{-1}$ dengan asam asetat 225 1.ha ${ }^{-1}$ untuk setiap waktu pengamatan ditampilkan pada Gambar 2. A. gangetica (L.) T. Anders menunjukkan dominansi yang terus meningkat dari 0 MSA hingga 5 MSA serta memiliki rerata SDR 41,41\% dalam 8 minggu. Tingkat dominansi tertinggi A. gangetica (L.) T. Anders terjadi pada 4 MSA dan 5 MSA yang mencapai 53,54\% dan 51,77\% . A. gangetica (L.) T. Anders memiliki tingkat dominasi yang tinggi hal ini diduga karna sifat dan cirinya. Ciri khas gulma adalah pertumbuhannya cepat, mempunyai daya saing kuat dalam memperebutkan faktor-faktor kebutuhan hidup, dan bijinya mempunyai sifat dormansi yang memungkinkan untuk bertahan hidup yang lama dalam kondisi yang tidak menguntungkan (Nasution, 1986 dalam Kurniawan, 2019).

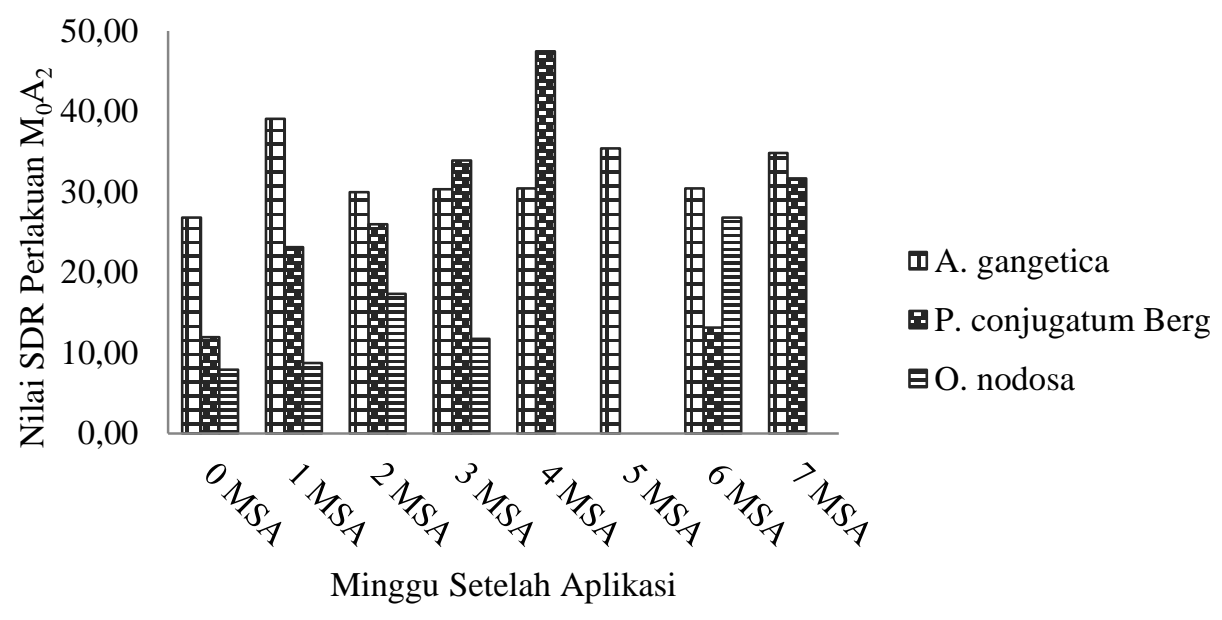

Gambar 3. Perbandingan tiga spesies gulma dominan akibat perlakuan metil metsulfuron 0 g.ha ${ }^{-1}$ dan asam asetat $315 \mathrm{ml}^{-h^{-1}}$

Perlakuan $\mathrm{M}_{0} \mathrm{~A}_{2}$ dengan dosis kombinasi metil metsulfuron 0 g.ha ${ }^{-1}$ dan asam asetat 315 1.ha ${ }^{-1}$, berdasarkan nilai rerata tertinggi untuk golongan daun lebar (A. gangetica $($ L.) T. Anders) dan untuk golongan rumputan ( $P$. conjugatum Bergh dan $O$. nodosa) pada Gambar 3. Dosis 
kombinasi yang berbeda menunjukan hasil yang cukup signifikan untuk menekan pertumbuhan gulma dominan A. gangetica (L.) T. Anders. Hal ini diduga karena pernambahan konsentrasi herbisida asam asetat pada perlakuan $\mathrm{M}_{0} \mathrm{~A}_{2}$ yang menyebabkan A. gangetica (L.) T. Anders sebagai gulma golongan daun lebar mengalami mortalitas. Asam asetat diaplikasikan pada dosis sekita 20\% untuk memberikan penekanan pada pertumbuhan vegetatif (Barker \& Prostak, 2009).

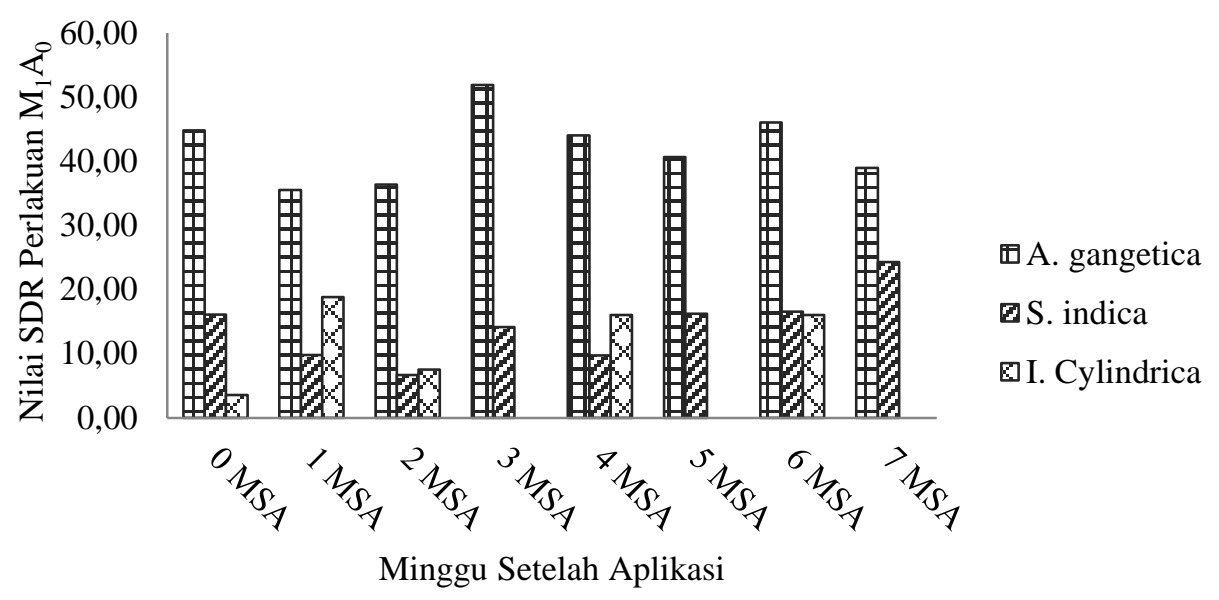

Gambar 4. Perbandingan tiga spesies gulma dominan akibat perlakuan metil metsulfuron 45 g.ha ${ }^{-1}$ dan asam asetat $0 \mathrm{ml}^{-h a^{-1}}$

Perlakuan $\mathrm{M}_{1} \mathrm{~A}_{0}$ dengan dosis kombinasi metil metsulfuron $45 \mathrm{~g} \cdot \mathrm{ha}^{-1}$ dan asam asetat 0 ml.ha ${ }^{-1}$, berdasarkan nilai rerata tertinggi untuk golingan daun lebar (A. gangetica (L.) T. Anders dan S. indica) dan untuk golongan rumputan (I. cylindrica) pada Gambar 4. Nilai SDR A. gangetica (L.) T. Anders dan S. indica dan I. cylindrica yang mengalami kenaikan dan penurunan pada setiap minggunya. Hal ini diduga karena dosis metil metsulfuron yang digunakan kurang tepat sehingga gulma tidak dapat dikendalikan pertumbuhannya. Suatu herbisida pada dosis atau konsentrasi tertentu dapat bersifat selektis, tetapi bila diturunkan atau dinaikkan berubah menjadi tidak selektif (Sukman \& Yakub, 2002).

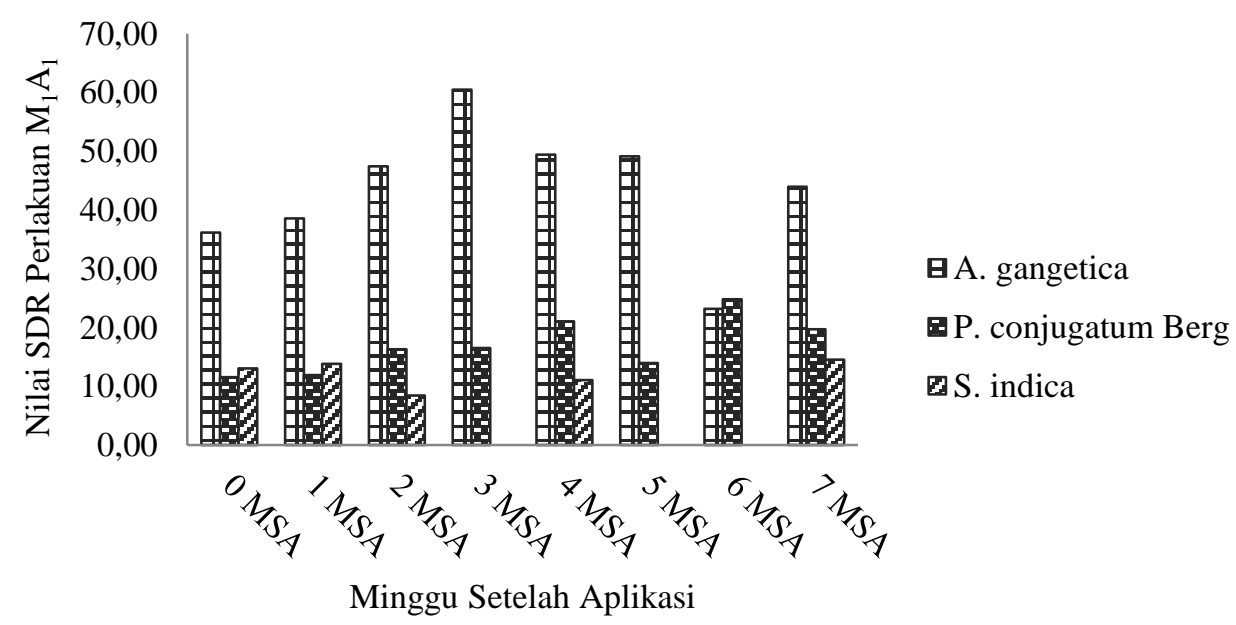

Gambar 5. Perbandingan tiga spesies gulma dominan akibat perlakuan metil metsulfuron 45 g.ha ${ }^{-1}$ dan asam asetat $225 \mathrm{ml} \mathrm{ha}^{-1}$ 
Perlakuan $\mathrm{M}_{1} \mathrm{~A}_{1}$ dengan dosis kombinasi metil metsulfuron $45 \mathrm{~kg} \cdot \mathrm{ha}^{-1}$ dan asam asetat 225 1.ha ${ }^{-1}$, berdasarkan nilai rerata tertinggi untuk golongan daun lebar (A. gangetica (L.) T. Anders dan S. indica) dan untuk golongan rumputan (P. conjugatum Bergh.) pada Gambar 5. A. gangetica (L.) T. Anders merupakan gulma yang paling dominan dari gulma lainnya. A. gangetica (L.) T. Anders sudah menunjukkan dominansinya hingga $36,16 \%$ sebelum dikendalikan dan terus mengalami peningkatan hingga 60,45\% pada 3 MSA. Peningkatan yang terjadi diduga karena dosis kombinsi herbisida $\mathrm{M}_{1} \mathrm{~A}_{1}$ kurang mampu mengendalikan A. gangetica (L.) T. Anders. Aplikasi menggunakan herbisida dalam dosis rendah kurang mampu menekan pertumbuhan gulma sehingga nilai SDR meningkat.

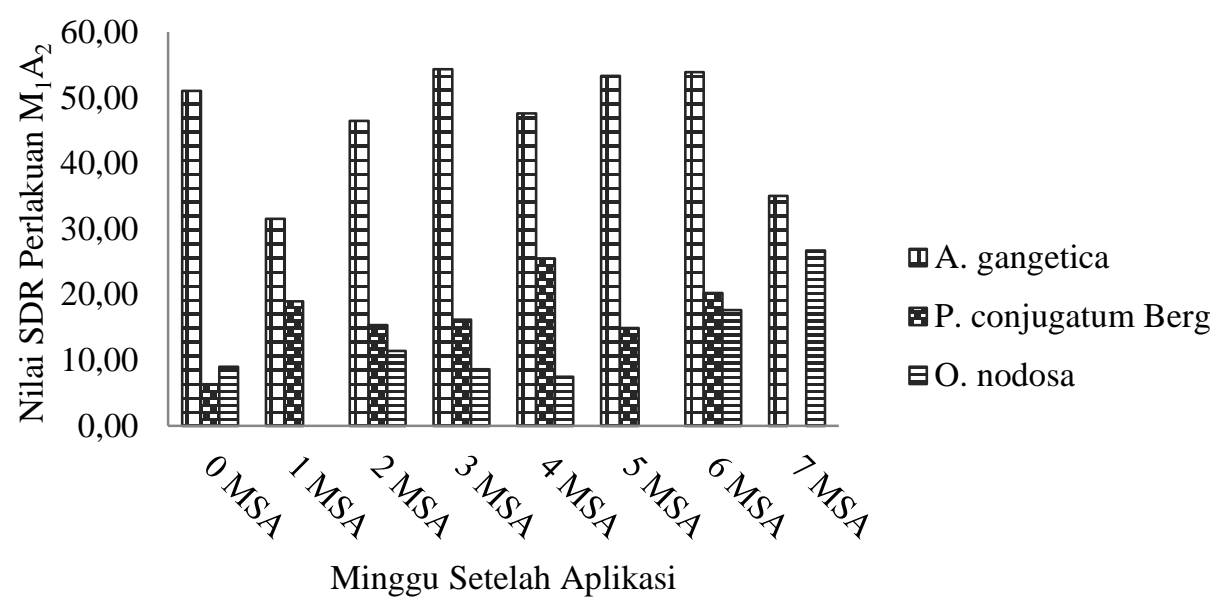

Gambar 6. Perbandingan tiga spesies gulma dominan akibat perlakuan metil metsulfuron 45 g.ha ${ }^{-1}$ dan asam asetat $315 \mathrm{ml}^{-h^{-1}}$

Perlakuan $\mathrm{M}_{1} \mathrm{~A}_{2}$ dengan dosis kombinasi metil metsulfuron 45 g.ha ${ }^{-1}$ dan asam asetat 315 1.ha ${ }^{-1}$, berdasarkan nilai rerata tertinggi untuk golongan daun lebar (A. gangetica (L.) T. Anders) dan untuk golongan rumputan ( $P$. conjugatum Bergh. dan $O$. nodosa) pada Gambar 6 . $P$. conjugatum Bergh. tidak dominan sebelum dikendalikan dengan nilai SDR 6,35\%. Dominansi meningkat pada 1 MSA hingga 6 MSA yang mencapai 20,27\% kemungkinan karena muncul individu baru yang berasal dari biji dorman. Biji memiliki masa dormansi yang pada kondisi yang kurang menguntungkan akan mampu bertahan hidup hingga waktu yang lama, karena biji gulma akan berkecambah pada lingkungan yang memungkinkan gulma tumbuh dengan baik (Sembodo, 2010). 


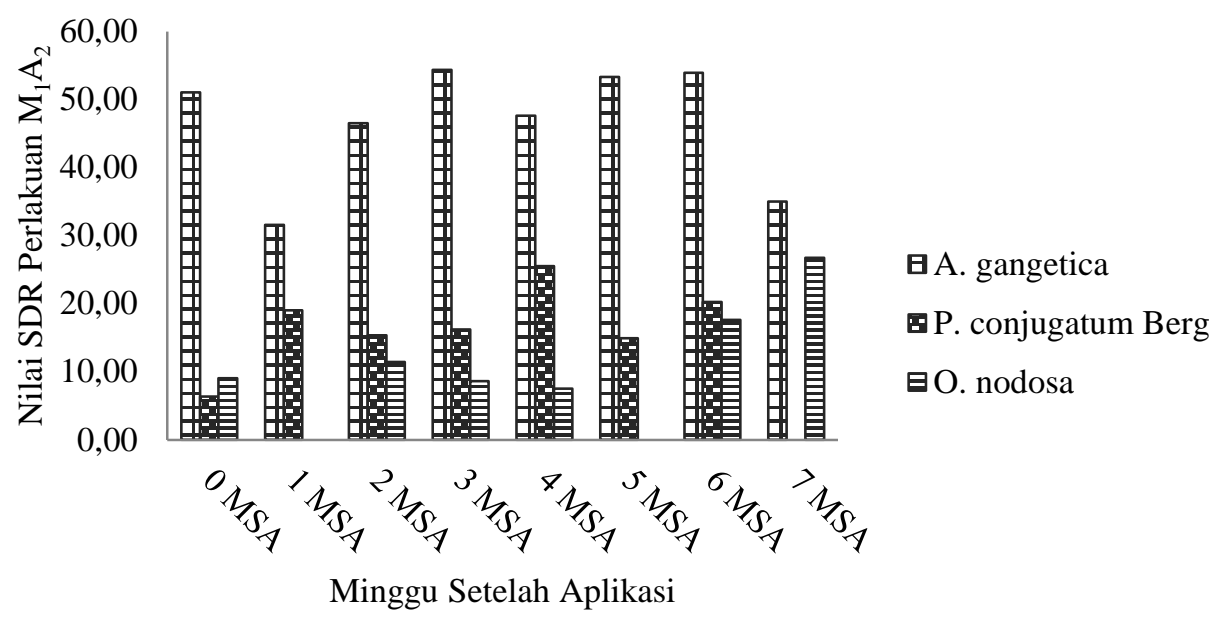

Gambar 6. Perbandingan tiga spesies gulma dominan akibat perlakuan metil metsulfuron 75 g.ha ${ }^{-1}$ dan asam asetat $0 \mathrm{ml}^{-h^{-1}}$

Perlakuan $\mathrm{M}_{2} \mathrm{~A}_{0}$ dengan dosis kombinasi metil metsulfuron $75 \mathrm{~g}^{\mathrm{h}} \mathrm{ha}^{-1}$ dan asam asetat 0 $\mathrm{ml} \mathrm{ha}^{-1}$, berdasarkan nilai rerata tertinggi untuk golongan daun lebar (A. gangetica (L.) T. Anders) dan untuk golongan rumputan ( $P$. conjugatum Bergh. dan I. cylindrica) pada Gambar 7. A. gangetica (L.) T. Anders mendominasi petak perlakuan hingga (50,14\%) sebelum aplikasi herbisida metil metsulfuron dan (42,35\%), setelah aplikasi herbisida gulma mengalami peningkatan dominasi pada 6 MSA dengan nilai SDR (40,89\%).

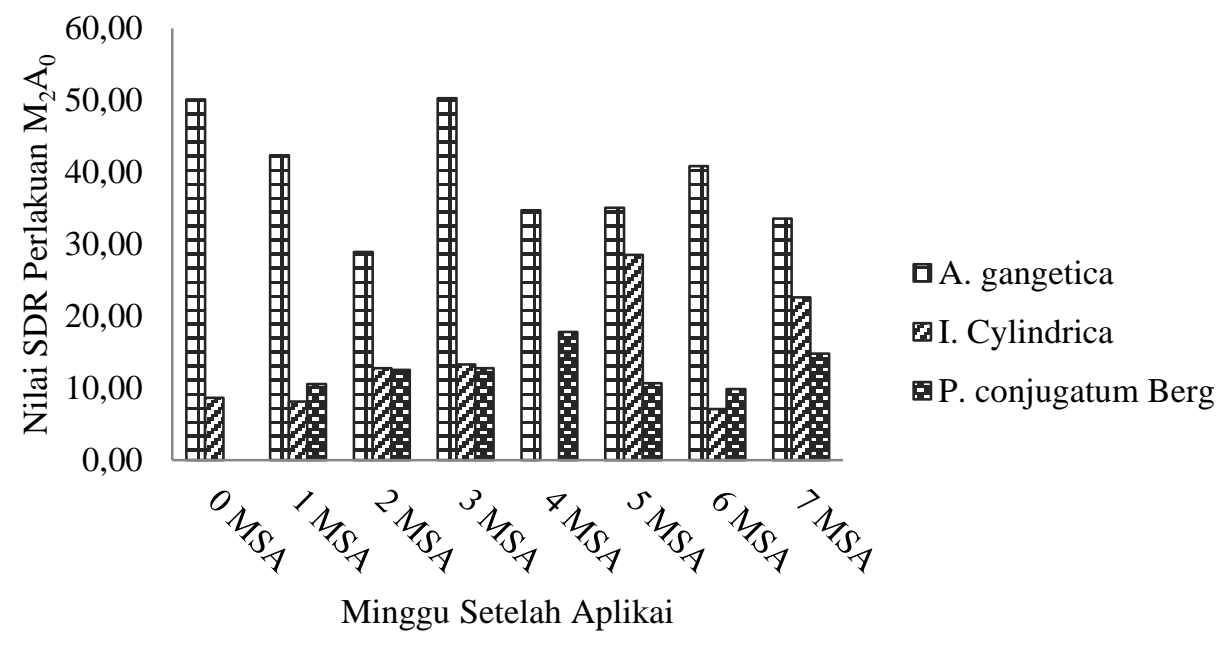

Gambar 7. Perbandingan tiga spesies gulma dominan akibat perlakuan metil metsulfuron 75 g.ha ${ }^{-1}$ dan asam asetat 0 ml.ha ${ }^{-1}$ 


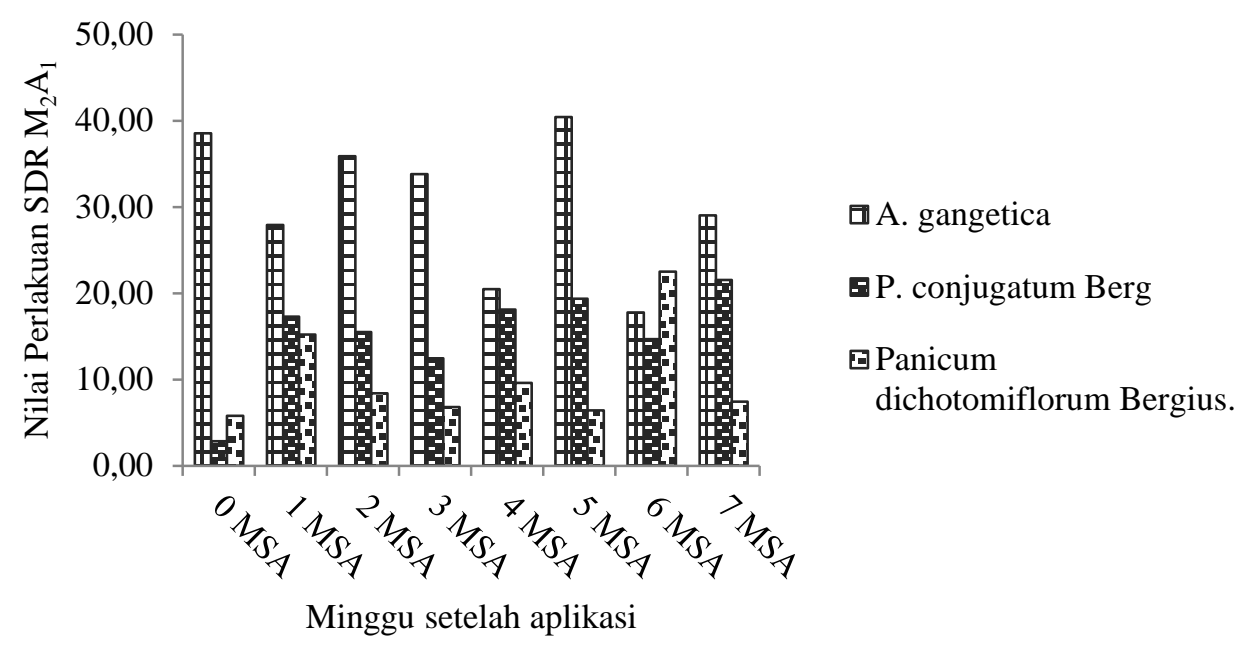

Gambar 8. Perbandingan tiga spesies gulma dominan akibat perlakuan metil metsulfuron 75 g.ha ${ }^{-1}$ dan asam asetat $225 \mathrm{ml}^{-h^{-1}}$

Perlakuan $\mathrm{M}_{2} \mathrm{~A}_{1}$ dengan dosis kombinasi metil metsulfuron $75 \mathrm{~kg} \cdot \mathrm{ha}^{-1}$ dan asam asetat 225 1.ha ${ }^{-1}$, berdasarkan nilai rerata tertinggi untuk golongan daun lebar (A. gangetica (L.) T. Anders) dan untuk golongan rumputan ( $P$. conjugatum Bergh. dan P. dycotomiflorum) pada Gambar 9. Pada 0 MSA A. gangetica (L.) T. Anders mendominasi dengan nilai SDR 40,41\% pada 5 MSA, dan nilai SDR turun pada 6 MSA $(17,78 \%)$ dan naik kembali 29,01\% pada akhir pengamatan.

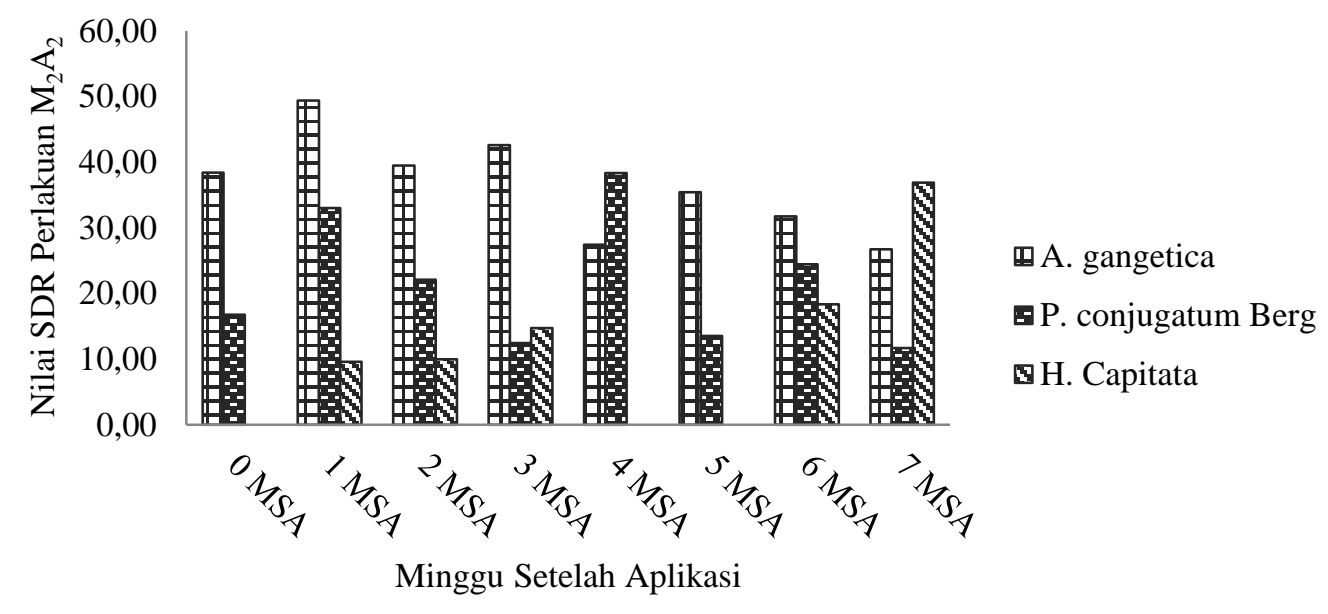

Gambar 9. Perbandingan tiga spesies gulma dominan akibat perlakuan metil metsulfuron 75 g.ha- ${ }^{-1}$ dan asam asetat 315 ml.ha ${ }^{-1}$

Perlakuan $\mathrm{M}_{2} \mathrm{~A}_{2}$ dengan dosis kombinasi metil metsulfuron 75 g.ha ${ }^{-1}$ dan asam asetat 315 1.ha ${ }^{-1}$, berdasarkan nilai rerata tertinggi untuk golongan daun lebar (A. gangetica (L.) T. Anders dan $H$. capitata) dan untuk golongan rumputan (P. conjugatum Bergh.) pada Gambar 9. A. gangetica (L.) menjadi gulma golongan berdaun lebar yang mendominasi sejak sebelum aplikasi kombinasi herbisida metil metsulfuron dan herbisida asam asetat dengan nilai SDR 38,43\%, setelah aplikasi A. gangetica (L.) mengalami peningkatan pada 1 MSA (SDR; 49,38\%) hingga 3 MSA (SDR 42,56\%) karena pertumbuhan biji-biji dorman yang berkecambah dan tumbuh. 


\section{KESIMPULAN}

Berdasarkan penelitian yang telah dilakuakan, dosis kombinasi herbisida yang efektif adalah metil metsulfuron 75 g.ha ${ }^{-1}$ dan asam asetat 315 1.ha ${ }^{-1}$. Gulma yang mendominasi pada tiap petak perlakuan adalah spesies golongan daun lebar yaitu A. gangetica, H. capitata, dan S. indica; sedangkan golongan rumput, yaitu P. dichotomyflorum dan P. conjugatum Bergh.

\section{DAFTAR PUSTAKA}

Badan Pusat Statistik. (2020). Ekspor minyak kelapa sawit menurut negara tujuan utama, 20122019. Retrieved February 20, 2020, from https://www.bps.go.id/statictable/2014/09/08/1026/ekspor-minyak-kelapa-sawit-menurutnegara-tujuan-utama-2012-2019.html

Barker, V. A., \& Prostak, R. G. (2009). Acetic acid alternative management of roadside vegetation. HortTechnology, 19(2), $346-352$.

Gultom, S., Zaman, S., \& Purnamawati, H. (2017). Periode kritis pertumbuhan kedelai hitam (Glycine max (L.) Merr) dalam berkompetisi dengan gulma. Buletin Agrohorti, 5(1), 45-54.

Hutapea, C., Syofian, M., \& Sudirman, A. (2015). Pengaruh berbagai jenis pupuk organik terhadap spesies gulma invasif. Jurnal Agro Industri Perkebunan, 3(1), 21-33. https://doi.org/10.25181/aip.v3i1.16

Kuniawan, A. 2019. Ketahanan herbisida paraquat diklorida terhadap waktu turun hujan serta daya kendalinya terhadap beberapa spesies gulma [Unpublished undergraduate thesis], Universitas Lampung.

Kuvaini, A. (2011). Penentuan konsentrasi efektif herbisida Prima Up 480 SL dan Meta Prima 20 WDG untuk mengendalikan gulma beringin. Jurnal Citra Widya Edukasi, 3(1), 1-9.

Madusari, S. (2016). Analisis tingkat kematian gulma Melastoma malabathricum menggunakan bahan aktif Metil metsulfuron pada tingkat konsentrasi yang berbeda di perkebunan kelapa sawit. Jurnal Citra Widya Edukasi, 8(3), 236-249.

Moenandir, J. (1993). Ilmu Gulma dalam Sistem Pertanian. PT. Raja Grafindo Persada.

Nugraha, M. A. S., Gunawan, S., \& Santi, I. S. (2018). Pengaruh Kualitas Panen Terhadap Losses Diperkebunan Kelapa Sawit Di Pt Wanasawit Subur Sumber Lestari 2. Jurnal Agromast, 3(1).

Oktavia, K., Pujisiswanto, H., Evizal, R., \& Susanto, H. (2019). Pengaruh aplikasi glifosat terhadap efikasi dan komposisi gulma pertanaman kelapa sawit tanaman menghasilkan muda. Jurnal Agro Industri Perkebunan, 7(1), 1-9. https://doi.org/10.25181/jaip.v7i1.978

Onarely, A., Riry, J., \& Wattimena, A. Y. (2016). Studi Komunitas Gulma Di Areal Pertanaman Pala (Mirystica Fragrans Houtt) Pada Stadium Tanaman Belum Menghasilkan Dan Menghasilkan Di Desa Rutong Kecamatan Leitimur Selatan Kota Ambon. Jurnal Budidaya Pertanian, 12(2), 80-88.

Pujisiswanto, H. (2012). Kajian daya racun cuka (asam asetat) terhadap pertumbuhan gulma pada persiapan lahan. Agrin, 16(1), 40-48. 
Pujisiswanto, H. (2015). Mekanisme dan efektifitas asam asetat sebagai herbisida terhadap gulma pada jagung (Zea mays L.) [Unpublished master's thesis]. Universitas Gadjah Mada.

Sembodo, D.R.J. (2010). Gulma dan Pengendaliannya. Graha Ilmu.

Sukman, Y., \& Yakub. (2002). Gulma dan Teknik Pengendaliannya (Edisi Revisi). PT Raja Grafindo Persada.

Umiyati, U. D. \& Kurniadie. (2018). Pengendalian gulma umum dengan herbisida campuran (amonium glufosinat $150 \mathrm{~g} / \mathrm{l}$ dan metil metsulfuron $5 \mathrm{~g} / \mathrm{l}$ ) pada tanaman kelapa sawit TBM. $J$. Pen. Kelapa Sawit, 26(1), 29-35. 